\title{
Uffizi Gallery monitoring for IAQ assessment
}

\author{
Cristina Carletti ${ }^{1, *}$, Gianfranco Cellai ${ }^{1}$, Cristina Piselli $^{1}$, Fabio Sciurpi $^{1}$, Giuseppe Russo ${ }^{2}$, \\ and Eike D. Schmidt ${ }^{2}$ \\ ${ }^{1}$ DIDA - Department of Architecture, University of Florence, 50121 Florence, Italy \\ ${ }^{2}$ Uffizi Gallery, 50122 Florence, Italy
}

\begin{abstract}
In museums, poor indoor air quality combined with unsuitable thermal and hygrometric conditions can affect the visitors and staff wellbeing as well as cause the deterioration processes of the exhibit objects. In order to assess indoor air quality of the museum, a survey was carried out in some rooms of the Uffizi Gallery of Florence by the researchers of the Laboratory of Environmental Physics of the University of Florence. Indoor temperature, relative humidity, chemical and microbiological pollutants were sampled, and the results analyzed and discussed. To do that a general methodology of investigation and evaluation of the results was defined and applied to several rooms of the Gallery. The presence of critical pollutant concentration was underlined and proper investigations on the HVAC system were scheduled. In this paper the results regarding a representative room are shown and discussed.
\end{abstract}

\section{Introduction}

As museums play an important role in society it is necessary to ensure and improve indoor air quality (IAQ) conditions to preserve the artefacts $[1,2]$ and provide well-being to visitors and staff [3]. It is frequently hard to manage the indoor air conditions and to reach a compromise between IAQ, well-being, preventive conservation and energy efficiency, since conservation requires by definition a very stable climate with short fluctuations, which imposes high demands to the air conditioning systems in order to meet those requirements and to reduce the process of exhibits degradation [4].

To assess indoor quality and the related exposure to air pollutants, emissions from various sources, such as occupants, building materials, maintenance products and equipment, including heating, ventilation and air conditioning systems (HVAC), must be considered as well as the duration of the exposure for the workers and the visitors in the museum. From a management point of view airborne pollutants rarely can be controlled and monitored individually; so, some pollutants must be identified as key pollutants for museum environments [5].

Most relevant parameters inside museums to be monitored are air temperature, relative humidity, carbon dioxide $\left(\mathrm{CO}_{2}\right)$, total volatile organic compounds (VOCs) and biological

\footnotetext{
* Corresponding author: cristina.carletti@unifi.it
} 
pollutants; the adverse effects of these pollutants on the artworks can be even increased by indoor high levels of temperature, relative humidity and ventilation effectiveness.

Carbon dioxide is emitted from human breath together with water vapor and can be used as an indicator of the effectiveness of ventilation in the museum. It has very little adverse effect on collections while its concentration above $1000 \mathrm{ppm}$ can cause adverse effect on human health.

Volatile organic compounds in museum indoor air occur in many species and from various sources: occupants (metabolic products, personal care products), cleaners and waxes (cleaning products with solvents, etc.), paints, pesticides (mold inhibitors, insecticides, fungicides, household disinfectants, etc.), adhesives, furnishing and clothing (carpet finishing components, tapestry, draperies, tissues, etc.), building materials (construction materials, furniture, etc.), HVAC systems sections and air inlet grids if near to pollution sources (vehicular exhaust, etc.), outdoor air [6]. VOCs are formed by numerous chemical compounds, belonging to classes of aromatic, halogenated and aliphatic hydrocarbons, aldehydes, esters, alcohols, ketones, terpenes, carboxylic acids, etc. If exposure to VOCs exceed the guidelines limits it can result in both acute and chronic health effects relate to the pollutants concentration and its exposure.

Main classes of biological pollutants which can affect IAQ in museums are mold and bacteria. As the mold growth is increased by high relative humidity values and air temperature higher than $25^{\circ} \mathrm{C}$, it can also be an indicator of poor ventilation quality. Among the numerous species of fungi only some of them are of prime interest in museum indoor environments [6]. In indoor air of museums, the main sources of biological aerosol are usually human being even though these pollutants can grow in the dust settled in the building and the HVAC sections. High total bacterial load (TBL) can be also related to the presence and growth of pathogen micro-organisms that can cause potentially hazardous diseases for humans (infectious processes, allergies or intoxication in the occupants).

There are many technical standards (mandatory or voluntary), guidelines and studies (national and international) that can be taken into account to establish a relationship between pollutant concentration, ventilation rates, quality indicators and health effects or even discomfort conditions [7]: one of the most important Standard concerning IAQ is ASHRAE Standard 62.1 that defines acceptable indoor air quality [8]. Some Italian Reports of Istituto Superiore di Sanità (ISS) dealing with indoor air quality are also available [9, 10], moreover, different occupational patterns of museums (workers and visitors) are included in different laws and standards from Ministero per i Beni e le Attività Culturali [11]. Other important guidelines establish maintenance protocols (inspection, cleaning) for Air Handling Units (AHU) and ductworks of the HVAC systems; moreover, limit values for dust, bacterial ad fungi in ductwork are available. National Air Duct Cleaners Association (NADCA) guidelines and international standards and those of Associazione Italiana Igienisti Sistemi Aeraulici (AIISA) are very important as there is a strong relation between indoor air quality and ductworks [10, 12-14].

In order to investigate the indoor air quality in the Uffizi Gallery of Florence, a preliminary survey with short-term monitoring was carried out in 2019 in some rooms of the museum. To assess indoor temperature, relative humidity, chemical and microbiological pollutants in the museum, an investigation strategy and assessment of the results was defined. In the paper results dealing with room 41 compared with those of the room 10 are presented. The survey aim is to underline the presence of critical issues in order to determine future long-term monitoring strategies to improve indoor air quality in the museum and its equipment.

\section{Materials and methods}


A general investigation strategy for the evaluation of the indoor air quality of museums was defined and combined with site inspections and interviews with the technical staff that pointed out some complaints dealing with poor air quality conditions in the Gallery rooms. This methodology was than applied to the Uffizi Gallery. The Gallery entirely occupies the first and second floors of the building constructed between 1560 and 1580 and designed by Giorgio Vasari. It is famous worldwide for its outstanding collections of ancient sculptures and paintings [15] from the Middle Ages to the Modern period.

\subsection{Investigation strategy}

Within the investigation strategy a general methodology was defined:

- Phase 1_collection of general data;

- Phase 2_definition of the monitoring strategies;

- Phase 3_sampling of indoor parameters and chemical and microbiological pollutants;

- Phase 4_comparison between the measured values and the recommended values;

- Phase 5_pollutants critical analysis and their correlation with possible pollution sources.

The described methodology was applied to several rooms of the Uffizi Gallery, chosen according to the importance of the artworks exhibited, the number of visitors, the air conditioning system and the potential critical issues for artworks conservation and for occupants well-being related to indoor air quality. The first three step of the methodology are reported in Figure 1. In particular, the HVAC system was investigated both from a theoretical point of view and with direct inspection (technical rooms, spaces for the passage of pipes, duct, etc.) in order to analyze the effectiveness of the system to maintain acceptable indoor air quality in the museum environment. Moreover, as the presence of visitors was very important, air pollution in the museum was sampled, for some representative rooms, both with the museum closed (used to define reference values) and the museum open. In every analyzed room of the Gallery the instruments were positioned in an appropriate location with the aim of collecting representative data and, at the same time, limiting visitors' interaction and ensuring the correct fruition of the rooms.

The health effects of the monitored pollutants were also related to the combination and synergy with chemical pollutants. In particular, microbiological analysis aimed at the total bacterial load (including bacteria that grown at a temperature range of $30 \div 37^{\circ} \mathrm{C}$ ) and the total Colony Forming Unit (CFU) in the bioaerosol. The measured values were compared with the recommended values from guidelines, laws, technical standards, scientific studies.

Finally, in the Phase 4 and 5 a comparison between the measured values with the recommended values and a critical analysis of the results was carried out. Moreover, the correlation of pollutants with HVAC system, maintenance procedures, cleaning procedures, etc. was investigated.

\begin{tabular}{|l||l||l|}
\hline 1_Collection of general data & 2_Monitoring strategies & 3_Sampling of LAQ \\
\hline Condition of rooms and equipment & Sampling objectives & Air temperature \\
Number of visitors & Rooms of the museums to assess & Relative humidity \\
Collection of documents and drawings & Set of instruments & Air velocity \\
Analysis of building materials & Time of sampling & Organic (VOCs) and inorganic \\
Analysis of the HVAC system and other & Duration and frequency of & pollutants $\left(\mathrm{CO}_{2}\right)$ \\
equipment Analysis of the objects exposed & sampling & \\
Collection of proper conservation conditions & Sampling location \\
& Active and passive sampling \\
& strategies \\
\hline
\end{tabular}

Fig. 1. Phase 1, 2, and 3 of the investigation methodology.

\subsection{Sampling tools and methods}


On the basis of the site inspection, and the indication of the technical staff of the Uffizi Gallery, the survey was conducted in some representative rooms. In Figure 2 and 3, the first and second floor plan of the Uffizi Gallery indicating the analyzed rooms are presented while in Table 1 the main characteristics of the analyzed rooms in the Uffizi Gallery are reported.

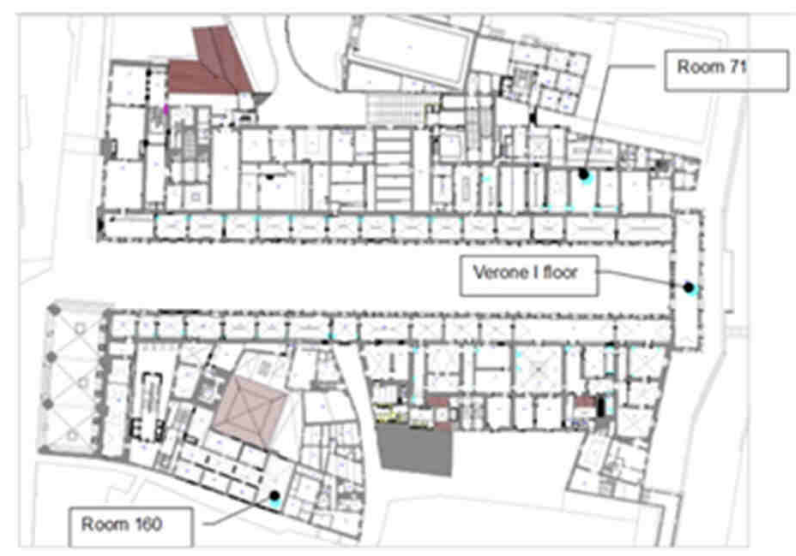

Fig. 2. First floor plan of the Uffizi Gallery indicating the analyzed rooms.

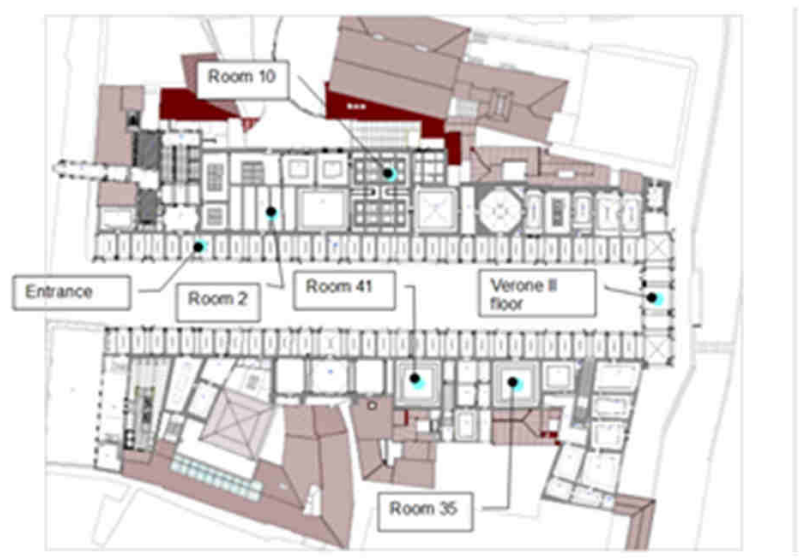

Fig. 3. Second floor plan of the Uffizi Gallery indicating the analyzed rooms.

The Uffizi Gallery is partially served by HVAC systems aimed at the control of air temperature and relative humidity in the different rooms. HVAC systems are managed by a remote monitoring and control system (Building automation Desigo ${ }^{\mathrm{TM}}$ ): from a central PC workstation the entire air conditioning system can be monitored, parameters and calibrations can be customized, samplings can be displayed in graphs form and diagrams, trend diagrams can be produced, batch job actions can be scheduled, and alarm messages from the system can be get. The control system also manages fire, intrusion and electrical systems.

As concerns the air conditioning of the museum, different AHUs provide heating, ventilating, and air-conditioning in the different rooms, while some of the investigated rooms are non-provided with air conditioning. In particular, HVAC system for room 41 has a variable percentage of air recirculation both in winter and summer conditions with a nominal air flow rate of $10000 \mathrm{~m}^{3} / \mathrm{h}$ (Figure 4). Air inlet is provided by linear grids (in the upper part of the room near the skylight) while air outlet grids are built-in the floor (Figures 
5 and 6). The AHU is located in a very narrow attic room and maintenance procedures can be particularly difficult (Figure 7).

Samplings, conducted to have a preliminary scenario of the problems correlated with the indoor air quality of the museum and the microclimatic parameters, were collected during 3 of June 2019 (with the gallery closed to the public) and 5 ad 6 of June 2019 (with the Gallery opened to the public); they started at 10 a.m. and finished at 5 p.m.

In the sampling days the presence of the public was calculated on the basis of the sold tickets which were in any case lower than the actual visitors: the 5 of June there were 7435 visitors while the 6 of June there were 7297 visitors.

Table 1. Main characteristics of the analyzed rooms in the Uffizi Gallery.

\begin{tabular}{|c|c|}
\hline $\begin{array}{l}\text { The entrance of the Gallery is at the second floor of the building } \\
\text { and overlooks a large corridor. It faces west with large windows. } \\
\text { Sampling was performed near the access control. }\end{array}$ & $\begin{array}{c}\text { Surface }=317,14 \mathrm{~m}^{2} \\
\text { High }=5,68 \mathrm{~m} \\
\text { Volume }=1801,35 \mathrm{~m}^{3}\end{array}$ \\
\hline $\begin{array}{l}\text { Verone (second floor) is connected with the entrance of the } \\
\text { Gallery. It is North, South and West oriented with large windows. } \\
\text { Sampling was performed near the west facing. }\end{array}$ & $\begin{array}{c}\text { Surface }=214,99 \mathrm{~m}^{2} \\
\text { High }=5,68 \mathrm{~m} \\
\text { Volume }=1221,14 \mathrm{~m}^{3}\end{array}$ \\
\hline $\begin{array}{l}\text { Room } 2 \text { is accessed from the entrance. Inside the room there is the } \\
\text { "Maestà di Ognissanti" by Giotto. The room has no external walls. } \\
\text { Samplings were carried out near the painting. }\end{array}$ & $\begin{array}{c}\text { Surface }=198,27 \mathrm{~m}^{2} \\
\text { High }=9,85 \mathrm{~m} \\
\text { Volume }=1952,96 \mathrm{~m}^{3}\end{array}$ \\
\hline $\begin{array}{l}\text { Room } 10 \text { is accessed from the adjacent " } 14 \text { th century" rooms. } \\
\text { Inside the room there is the "Primavera" by Sandro Botticelli. The } \\
\text { room has one East oriented windowless external wall. Samplings } \\
\text { were carried out near the painting. }\end{array}$ & $\begin{array}{c}\text { Surface }=146,34 \mathrm{~m}^{2} \\
\text { High }=8,93 \mathrm{~m} \\
\text { Volume }=1306,82 \mathrm{~m}^{3}\end{array}$ \\
\hline $\begin{array}{l}\text { Room } 35 \text { is accessed from a large corridor. Inside the room there } \\
\text { is the "adorazione dei Magi"of Leonardo da Vinci. The room has } \\
\text { one West oriented windowless external wall. Samplings were } \\
\text { carried out near the painting. }\end{array}$ & $\begin{aligned} \text { Surface } & =146,80 \mathrm{~m}^{2} \\
\text { High } & =6,61 \mathrm{~m} \\
\text { Volume } & =970,35 \mathrm{~m}^{3}\end{aligned}$ \\
\hline $\begin{array}{l}\text { Room } 41 \text { is accessed from a large corridor. Inside the room there } \\
\text { is the Sacra Famiglia called "Tondo Doni" of Michelangelo } \\
\text { Buonarroti. The room has one West oriented windowless external } \\
\text { wall. Samplings were carried out near the painting. }\end{array}$ & $\begin{aligned} \text { Surface } & =140,91 \mathrm{~m}^{2} \\
\text { High } & =6,61 \mathrm{~m} \\
\text { Volume } & =931,41 \mathrm{~m}^{3}\end{aligned}$ \\
\hline $\begin{array}{l}\text { Verone (first floor) has views on every orientation with large } \\
\text { windows. Sampling was performed near the North facing. }\end{array}$ & $\begin{array}{c}\text { Surface }=201,04 \mathrm{~m}^{2} \\
\text { High }=8,17 \mathrm{~m} \\
\text { Volume }=1642,50 \mathrm{~m}^{3}\end{array}$ \\
\hline $\begin{array}{l}\text { Room } 71 \text { is accessed from a large corridor. Inside the room there } \\
\text { is the "Scudo con testa di Medusa" of Michelangelo Merisi from } \\
\text { Caravaggio (1597). The room has non external walls. Samplings } \\
\text { were carried out near the painting. }\end{array}$ & $\begin{aligned} \text { Surface } & =69,28 \mathrm{~m}^{2} \\
\text { High } & =8,02 \mathrm{~m} \\
\text { Volume } & =555,62 \mathrm{~m}^{3}\end{aligned}$ \\
\hline $\begin{array}{l}\text { Room } 160 \text { houses the collection donated by Contini-Bonacossi. } \\
\text { Inside the room, paintings and marble statues are exhibited. The } \\
\text { room has North-West oriented windowless external wall and a } \\
\text { skylight. Samplings were carried out near one of the marble statue }\end{array}$ & $\begin{aligned} \text { Surface } & =89,10 \mathrm{~m}^{2} \\
\text { High } & =3,17 \mathrm{~m} \\
\text { Volume } & =282,45 \mathrm{~m}^{3}\end{aligned}$ \\
\hline
\end{tabular}




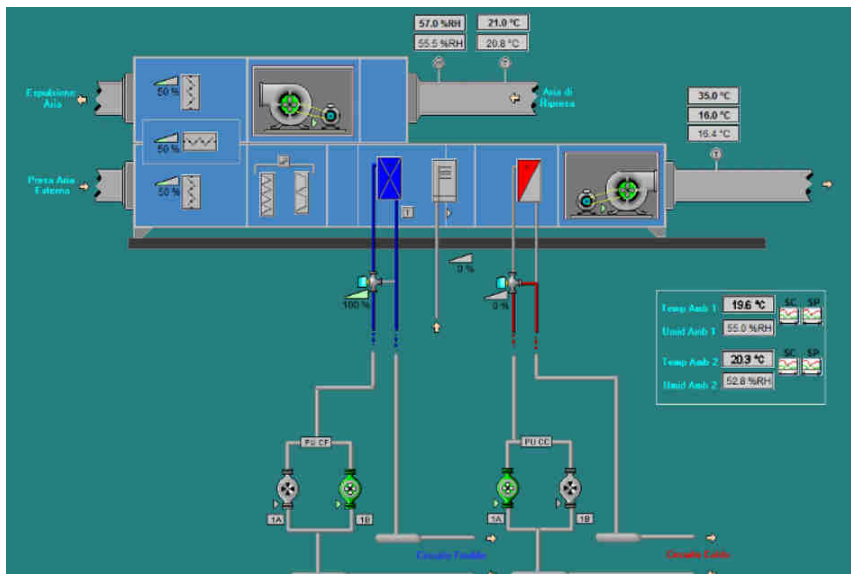

Fig. 4. AHU control system of room 41 .

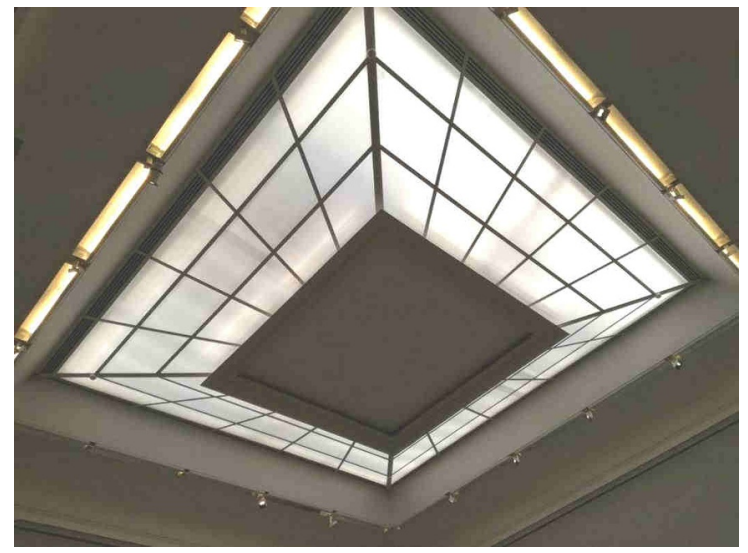

Fig. 5. Room 41: linear air inlet grids near the skylight.

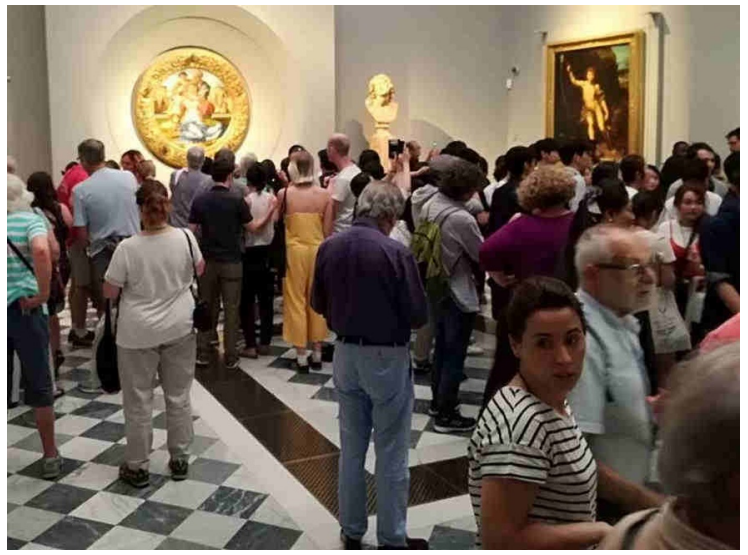

Fig. 6. Room 41: air outlet grids built-in the floor. 


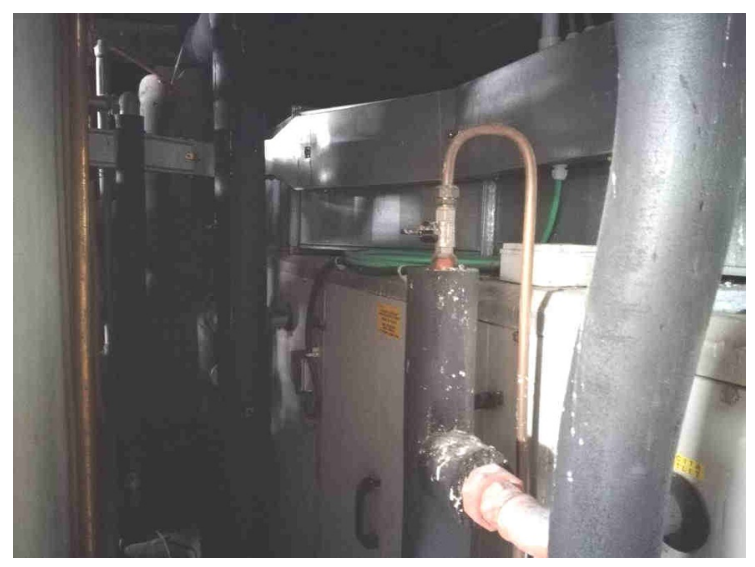

Fig. 7. Room 41: AHU in the attic room.

Collected data were reported in graphs, reference values of guidelines, standards and cut-off values of different pollutant concentrations were also underlined. Temperature and relative humidity ranges were highlighted together with recommended values for object proper conservation.

In particular, in room 71 and Verone - Second floor - samples were collected in two different positions (A and B) and in rooms 10, 35, and 41 samples were collected both with museum closed and the museum opened to the public.

To sample environmental parameters (dry and wet bulb temperature, air velocity and $\mathrm{CO}_{2}$ concentration), a microclimatic station with datalogger, positioned to a high of 1,6 m from floor, collecting samples every minute for 2 hours, was used with the following probes:

- psychrometer (accuracy $0,10^{\circ} \mathrm{C} \div 0,13^{\circ} \mathrm{C}$ with air temperature $0^{\circ} \mathrm{C} \div 20^{\circ} \mathrm{C} ; 2 \%$ (UR $15 \div 40 \%) ; 1 \%(40 \div 70 \%) ; 0,5 \%(70 \div 98 \%)$; measure range $\mathrm{t}_{\mathrm{db}}: 25 \div 150^{\circ} \mathrm{C}, \mathrm{t}_{\mathrm{wb}}: 0 \div 60^{\circ} \mathrm{C}, \mathrm{RH}$ : $0 \div 100 \%)$

- anemometer (accuracy $0,05 \mathrm{~m} / \mathrm{s}(0 \div 0,5 \mathrm{~m} / \mathrm{s}) ; 0,1 \mathrm{~m} / \mathrm{s}(0,5 \div 1,5 \mathrm{~m} / \mathrm{s}) ; 4 \%(>1,5 \mathrm{~m} / \mathrm{s})$ measure range $0 \div 20 \mathrm{~m} / \mathrm{s})$;

- $\mathrm{CO}_{2}$ probe (accuracy $3 \%$ measure range, measure range $0 \div 3000 \mathrm{ppm}$ ).

The VOCs monitoring was carried on in close proximity to the microclimatic station with active sampling of a 5 liters air volume collected in nalophan bags, afterwards sent to an external laboratory to be analyzed; quantitative and qualitative VOCs analysis was carried out according with Gas Chromatography-Mass Spectrometry (GC/MS) method [16]. For VOCs the cut-off value was settled at $1 \%$ of the air sample [17]. Biological analysis (TBL and molds) was carried on both with active and passive sampling methods. During active sampling air flow was collected with a surface air system impactor with a sampling rate of $100 \mathrm{l} /$ minute positioned in close proximity to the microclimatic station, to a high of 1,60 m from floor. Sampling rate and consequently the total air volume $(0,3-0,5$ $-1 \mathrm{~m}^{3}$ ) varied for different occupational pattern of the museum room. In order to collect information about biological pollution due to the passage of people and the air flows from the ventilation systems, the total biological pollution was also collected by passive sampling for 2 hours, using Petri dishes positioned near the microclimatic station ( $\Phi=90 \mathrm{~mm}$, Plate Count Agar for microbial growth and Sabouraud Dextrose Agar for mold growth). Both sample dishes (active and passive sampling) were sent to an external laboratory to be incubated at proper temperature-time range (three days at $30^{\circ} \mathrm{C}$ for $\mathrm{TBL}$ and five days at $25^{\circ} \mathrm{C}$ for molds) and afterwards analyzed to determine the CFU both for bacteria than for molds according to ISS Report [10]. 
In Figure 8, the microclimatic station and the surface air system impactor for active biological analysis are presented.

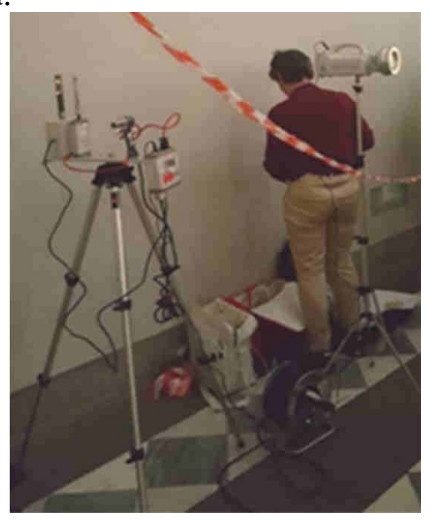

Fig. 8. Microclimatic station to sample dry and wet bulb temperature, air velocity, and $\mathrm{CO}_{2}$ concentration (left). Surface air system impactor for active biological analysis - TBL and molds (right).

\section{Sampling results}

The results of the sampling are reported for air temperature and relative humidity, carbon dioxide concentration, total volatile organic compounds and biological pollutants for the room 41 of the Uffizi Gallery. In Figure 9, the minimum, mean and maximum values sampled are reported for air temperature, relative humidity and carbon dioxide concentration in room 41 while, in Figure 10, the results of the sampling carried out for biological and chemical pollutants are presented.

For air temperature and relative humidity recommended ranges for correct conservation are respectively $19 \div 25^{\circ} \mathrm{C}$ and $45 \div 65 \%$ [11], while for carbon dioxide a concentration of 1000 is considered as limit value as is reported in Table 2 . The sampled compared with the recommended limits shows almost acceptable values for temperature and relative humidity and an acceptable $\mathrm{CO}_{2}$ concentration.

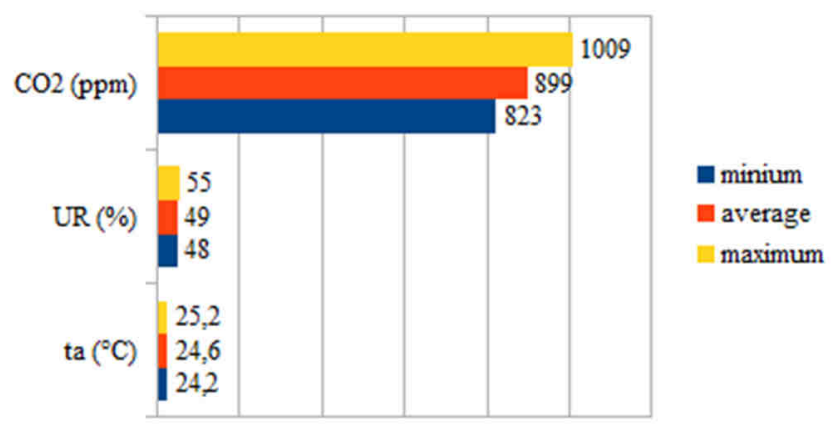

Fig. 9. Minimum, mean, and maximum values for carbon dioxide, relative humidity and air temperature in room 41 of the Uffizi Gallery. 


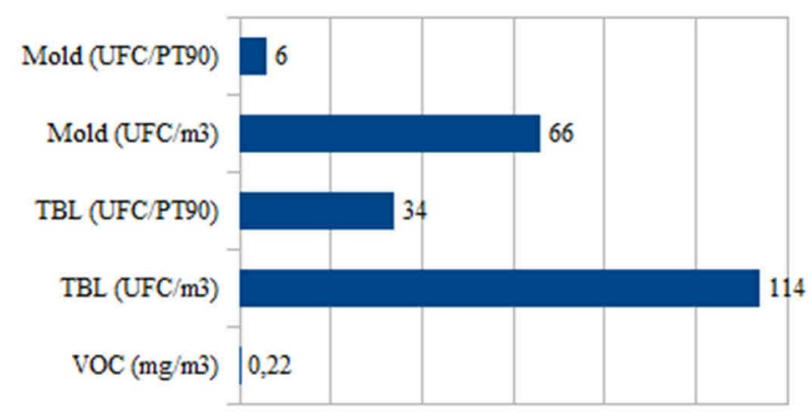

Fig. 10. Values for biological and chemical pollutants sampling in room 41 of the Uffizi Gallery. Legend: $\mathrm{TBL}=\mathrm{Total}$ Bacterial Load, $\mathrm{VOC}=$ Volatile Organic Compounds.

In Table 3, ranges of acceptable level for VOCs are reported. The values compared with the recommended limits shows acceptable concentrations of the pollutants. For VOCs concentration, European Standards suggest limit values for total VOCs; those can be used as reference values for museum IAQ assessment.

Table 2. $\mathrm{CO}_{2}$ concentration limit values [18].

\begin{tabular}{|c|c|}
\hline $\mathbf{C O}_{2}$ concentration & $\mathbf{C O}_{2}$ assessment \\
\hline $\mathrm{CO}_{2}$ beneath $1800 \mathrm{mg} / \mathrm{m}^{3}(1000 \mathrm{ppm})$ & Acceptable level, harmless \\
\hline $\begin{array}{c}\mathrm{CO}_{2} \text { between } 1800 \mathrm{mg} / \mathrm{m}^{3}(1000 \mathrm{ppm}) \\
\text { and } 3600 \mathrm{mg} / \mathrm{m}^{3}(2000 \mathrm{ppm})\end{array}$ & High level \\
\hline $\mathrm{CO}_{2}$ higher than $3600 \mathrm{mg} / \mathrm{m}^{3}(2000 \mathrm{ppm})$ & Unacceptable level \\
\hline
\end{tabular}

Table 3. VOCs concentration limit values [18].

\begin{tabular}{|c|c|}
\hline VOCs concentration & VOCs assessment \\
\hline$<0,200 \mathrm{mg} / \mathrm{m}^{3}$ & Comfort level \\
\hline $0,200-3 \mathrm{mg} / \mathrm{m}^{3}$ & Acceptable level \\
\hline $3-25 \mathrm{mg} / \mathrm{m}^{3}$ & Discomfort level \\
\hline$>25 \mathrm{mg} / \mathrm{m}^{3}$ & Unacceptable level - toxicity \\
\hline
\end{tabular}

These guidelines suggest a total VOCs concentration range between 0,200 and $3 \mathrm{mg} / \mathrm{m}^{3}$ as acceptable level; moreover, any component can't exceed $50 \%$ of the value identifying its class. Some VOCs classes were not detected (halogen-aliphatic, halogen-aromatic, halogenunsaturated, nitrogen-aromatic, oxygen-acid, ether, oxygen-acid, phenol, sulfur-mercaptan, sulfur-sulphide). For the other VOCs classes the cut-off value of the compound was set at $1 \%$ [17]; it represents the pollutant concentration in the compound that can be considered significantly present. The sum of the concentration values of the individual VOCs classes highlights the more present classes in the monitored rooms, such as the aldehydes and alcohols.

European guidelines suggest limit values for biological pollution (bacteria and molds) for non-industrial destinations and can be taken as reference values also for ductwork 
hygienic conditions in proximity of air inlet grids. The recommended concentration values for biological pollutants are reported in Table 4.

Collected molds belong to the Aspergillus and Penicillium genera (environmental molds). The first are ubiquitous and often monitored in different environments; in particular, Flavus and Fumigatus (classified in D.lgs.81/2008 All. 46 [12] as allergenic mold) species were identified, while Aspergillus niger was not identified. Even Penicillum genera can be associated with respiratory tract disorders in predisposed or immunosuppressed subjects.

In general, a comparison between room 10 [15] and room 41 can be made on the basis of the characteristics of the HVAC system and the indoor pollution values sampled (Table 5). In particular, the comparison between the air inlet flows and the air distribution in the room underlines the importance of the air inlet and outlet grids proper placing to improve the ventilation effectiveness and the consequent pollutant dilution: these can be really important when pathogens are present in the museum air.

Table 4. Recommended values in $\mathrm{CFU} / \mathrm{m}^{3}$ of biological concentration [13].

\begin{tabular}{|c|c|c|}
\hline Biological pollution level & Bacterial pollution $\left(\mathrm{CFU} / \mathbf{m}^{3}\right)$ & Mold pollution $\left(\mathrm{CFU} / \mathbf{m}^{\mathbf{3}}\right)$ \\
\hline Very low & $<50$ & $<25$ \\
\hline Low & $<100$ & $<100$ \\
\hline Intermediate & $<500$ & $<500$ \\
\hline High & $<2000$ & $<2000$ \\
\hline Very High & $>2000$ & $>2000$ \\
\hline
\end{tabular}

Table 5. Comparison among room 10 and room 41.

\begin{tabular}{|c|c|c|c|c|c|c|c|}
\hline Room & AHU & $\begin{array}{c}\text { Volume } \\
\left(\mathbf{m}^{3}\right)\end{array}$ & $\begin{array}{c}\text { Air flow } \\
\left(\mathbf{m}^{\mathbf{3}} / \mathbf{h}\right)\end{array}$ & $\begin{array}{c}\mathbf{C O} 2 \\
(\mathbf{p p m})\end{array}$ & $\begin{array}{c}\mathbf{V O C} \\
\left(\mathbf{m g} / \mathbf{m}^{3}\right)\end{array}$ & $\begin{array}{c}\mathbf{T B L} \\
\left(\mathbf{C F U} / \mathbf{m}^{3}\right)\end{array}$ & $\begin{array}{c}\mathbf{M o l d} \\
\left(\mathbf{C F U} / \mathbf{m}^{3}\right)\end{array}$ \\
\hline 10 & $\begin{array}{c}\text { Air inlet and } \\
\text { outlet grids near } \\
\text { the skylight }\end{array}$ & 1306 & 8000 & 1442 & 0,35 & 180 & 19 \\
\hline $\begin{array}{c}\text { Air inlet grids } \\
\text { near the skylight } \\
\text { and air outlet } \\
\text { grids built-in the } \\
\text { floor }\end{array}$ & 931 & 10000 & 899 & 0,22 & 114 & 66 \\
\hline
\end{tabular}

\section{Analysis of the results}

From the analysis of the results some critical aspects can be summarize as follows:

- some high rooms can present temperature stratification problems together with a poor effectiveness of mechanical ventilation due to the position of the air inlet-outlet grids; this can result in an increasing $\mathrm{CO}_{2}$ concentration with the same boundary condition of the HVAC system (air flow and air change rate) in different rooms such as room 41 and room 10 where maximum concentration with museum opened respectively is 889 and 1442 ppm;

- the control of relative humidity can be put in relation with the air treatments in the AHU when it works out of the "standard" boundary conditions; 
- the variation of the air temperature and relative humidity must be carefully assessed to guarantee optimal conservative condition of the exposed object, in particular paintings on wood;

- the best conditions are those that simultaneously guarantee air temperature and relative humidity values within the comfort range and the conservative range;

- carbon dioxide concentration depends both to external environment $\left(\mathrm{CO}_{2}=400 \mathrm{ppm}\right)$ and the presence of visitors and staff in the museum;

- $\mathrm{CO}_{2}$ concentration trend and VOCs trend are very similar, so strategies aimed at carbon dioxide concentration control can be effective also for VOCs control;

- aldehydes and alcohols are the most present VOCs classes; in addition to the pollutants associated with furnishings and cleaning products, the concentration of these pollutants can be also related to the presence of visitors;

- the monitored room can nevertheless be considered as a comfortable one as regards VOCs concentration in accordance with the European guidelines limit values;

- the different values of biological sampled pollution mostly depend on the sampling technique as passive sampling does not force the microorganisms collection of and lower values are therefore expected;

- as regards biological pollution the following observations can be made: total bacterial load belongs to the "low" pollution level $\left(<500 \mathrm{CFU} / \mathrm{m}^{3}\right)$ and molds concentration belongs to the "low" pollution level $\left(<100 \mathrm{CFU} / \mathrm{m}^{3}\right)$. Nevertheless, sampled values point out that biological and chemical indicators of indoor air quality should be taken constantly under control;

- as for the carbon dioxide and VOCs concentration related to HVAC system hygienic conditions and air distribution in the rooms, future investigations must be carried out with longer sampling duration compared to the punctual screening reported in the paper.

Moreover, some general strategies are suggested for the analyzed museum:

- check the compositions of detergents and disinfectants for the presence of VOCs;

- check how to use sanitizers and disinfectants;

- check the composition of glues and paints used for any maintenance interventions in relation to the presence of VOCs;

- as for the biological pollution, sampling of specific pollutants must be carried out both in the air ducts and in the filters before and after the maintenance procedures;

- specific contaminants must be monitored to avoid deterioration effects on the exhibited artworks. As for the VOCs pollution a deep investigation of the more representative classes is suggested at least for 8 hours due to the collected complaints of the workers in the museum in accordance to the DL 81/2008 and ACGIH (American Conference of Governmental Industrial Hygienists) that define both threshold Limit Value - Time Weighted Average - and Threshold Limit Value - Short Term Exposure Limit - that can be taken as reference limits respectively for workers and visitors of the Uffizi Gallery.

\section{Conclusions}

The paper presents the investigation strategy applied to the Uffizi Gallery of Florence. In some representative rooms a short term-monitoring was carried out to underline the concentration of chemical ( $\mathrm{CO}_{2}$, VOCs) and biological pollutants (TBL and molds) also in relation to microclimatic parameters (ta, RH). In particular, results of the short-term samplings carried out in room 41 compared with those of the room 10 are presented ad discussed.

Even if no pathogen was detected, indoor air quality in the museum can be improved thanks to better maintenance strategies of the building and with the improvement of hygienic maintenance procedures of the HVAC systems (ductwork, grids, filters, etc.). 
Moreover, indoor air pollutant should be assessed with a long-term monitoring even to relate the presence to the visitors and the effectiveness of ventilation in the rooms.

\section{Acknowledgments}

The authors would like to acknowledge the museum staff for providing support and cooperation during the process of collecting data and the IDIS Laboratory, especially in the person of Elena Baistrocchi, for the collaboration in the analyses of chemical and microbiological monitoring.

\section{References}

1. G. Thomson, The Museum Environment, $2^{\text {nd }}$ ed. (Elsevier Butterworth-Heinemann, London, 1986)

2. F. Sciurpi, C. Carletti, L. Pierangioli, IOP Conf. Ser.: Mater. Sci. Eng. 364, 012023 (2018)

3. H. Entradas Silva, F.M.A. Henriques, T.A.S. Henriques, G. Coelho, Build. Environ. 104, 21-34 (2016)

4. R.P. Kramer, H.L. Schellen, A.W.M. van Schijndel, Energ. Buildings 130, 286-294 (2016)

5. J. Tetreault, J. Cult. Herit. 6 (1), 89-90 (2003)

6. M. Maroni, B. Seifert, T. Lindvall, Indoor air quality. A comprehensive reference book (Elsevier, Amsterdam, 1995)

7. D. Khovalyg, O.B. Kazanci, H. Halvorsen, I. Gundlach, W.P. Bahnfleth, J. Toftum, B.W. Olesen, Energ. Buildings 213, 109819 (2020)

8. American Society of Heating, Refrigerating and Air Conditioning Engineers, ASHRAE Standard 62.1.2004 "Ventilation for Acceptable IAQ” (2004)

9. ISS, Workshop "La qualità dell'aria indoor: attuale situazione nazionale e comunitaria. L'esperienza del Gruppo di Studio Nazionale sull'Inquinamento Indoor" (2014)

10. ISS, Report 13/37 “Strategie di monitoraggio dell'inquinamento di origine biologica dell'aria in ambiente indoor" (2013)

11. MIBAC, D.M. 10 maggio 2001 Allegato A - Atto di indirizzo sui criteri tecnicoscientifici e sugli standard di funzionamento e sviluppo dei musei. Ambito V Sicurezza G. U. 19 ottobre 2001 n.244 S.O.

12. D.lgs. 9 aprile 2008 n. 81 Testo unico sulla salute e sicurezza sul lavoro - G. U. 30 Aprile 2008 n.101 S.O.

13. European Concerted Action Indoor air quality \& its impact on man (COST Project 613), Reports No. 11 and 12 Guidelines for Ventilation Requirements in Buildings (1992)

14. National Air Duct Cleaners Association, NADCA Standard "Assessment, Cleaning, and Restoration of HVAC Systems" (2013)

15. C. Carletti, G. Cellai, F. Sciurpi, G. Russo, E.D. Schmidt, IOP Conf. Ser.: Mater. Sci. Eng. 949, 012016 (2020)

16. EPA, EPA Air Method, Toxic Organics - 15 (TO-15): Determination of Volatile Organic Compounds (VOCs) in Air Collected in Specially-Prepared Canisters and Analyzed by Gas Chromatography/Mass Spectrometry (GC/MS) (1999) 
17. EC, Regulation N. 1272/2021 Classification, labelling and packaging of substances and mixtures (2008)

18. ISTISAN, Rapporto ISTISAN 16/15 - Presenza di $\mathrm{CO}_{2}$ e $\mathrm{H}_{2}$ in ambienti indoor conoscenze attuali e letteratura scientifica in materia (2016) 